\title{
In vitro anticancer activity of methanol extract of Cladophora spp. against HT-29 cell line
}

\author{
Shanthi, N., Murugesan, S and Kotteswari, M \\ "Division of Algal Biotechnology and Bionanaotechnology, PG and Research Dept of Botany, Pachaiyappa's \\ College, Chennai-600 030.
}

\begin{abstract}
The anticancer activity of the marine alga Cladophora spp. against HT-29 colon cancer cell line was studied. In the present investigation crude extract of seaweed was prepared by using soxhlet apparatus. Methanol was used as solvent for extraction. In vitro anticancer activity of seaweed at various concentrations (7.8 to $1000 \mu \mathrm{g} / \mathrm{mL}$ ) were studied against the chosen cell line by using MTT assay (3-(4, 5-dimethyl thiazol 2)2, 5-diphenyl tetrazolium bromide, a yellow tertrazol). The most potent antitumor activity has been shown at the concentration $7.8 \mu \mathrm{g} / \mathrm{mL}$ and $400 \mu \mathrm{g} / \mathrm{mL}$ of Cladaphora spp. extract on HT-29 colon cancer cell line.
\end{abstract}

Keywords: MTT Assay, HT-29 colon cancer cell line, Cladaphora spp,

\section{Introduction}

Seaweed is large and diverse groups that are rich in active metabolites and a source of novel ingredients for functional foods. Many types of the seaweed have been used as food in some part of the world. Some seaweed used as a traditional medicine because they are rich in lipid, minerals, vitamin and several bioactive compounds like polysaccharides, proteins, lipids and polyphenols, with antibacterial, antifungal, antiviral properties, etc., $(1 \& 2)$ and used in the development of new pharmaceutical agents (3). There are a number of studies evidenced that the anticancer effect of fucoidans, but no review available to speculate the fucoidan anticancer action. Recent studies evidenced that fucoidan has strong antitumor activity and exhibited important roles against human cancer cell lines ( 4 and 5). Fucoidan was found to be able to suppress the growth of tumor cells in vivo and activate the immune system against tumors $(6,7,8,9,1 \& 11)$

Cancer is most common and serious disease; it slaughters societies more than tuberculosis, malaria and HIV/AIDS combined (12). A total of $12.5 \%$ of deaths worldwide is due to cancer and 12.1 million cancer cases were in $2007,45 \%$ in developed countries and the remaining $55 \%$ in developing countries ( $13 \& 14$ ). Colorectal cancer is the third most common cancer in the world, with nearly 1.4 million new cases diagnosed in 2012 (15). Moreover, the incidence of this disease has increased steadily in recent years [16]. Despite advances in therapeutic interventions over the past few decades, the mortality rate of patients diagnosed with colorectal cancer remains approximately $40 \%$, mainly due to metastasis to the liver [17]. Chemotherapy is usually the first line treatment to cure cancers. It produces lots of side effects like baldness, vomiting, canker sores, diarrhoea, loss of appetite, nausea and fatigue. Cancer treatments do not have potent medicine as the currently available drugs are causing side effects in some instances. A variety of algae has anti proliferative and anti-inflammatory activities. In vivo and in vitro studies on seaweed constituents have been conducted to explicate the antimutagenic mechanisms of underlying the potential anticarcinogenic effects of kelp and red algae against colon and breast cancers (18 \& 19).

Many studies have focused on water soluble antitumor active substances from various marine algae, however, most anticancer agents have not been used clinically because of their undesirable side effects on normal cells (20). According to existing literature, more than ten new experimental antitumor agents derived from marine sources have entered clinical trials, including bryostatin-1, aplidine, ecteinascidin-743 (ET- 743), Kahalalide F, as well as derivatives of dolastatin such as TZT-1027 and LU 103793 (21). Many Ayurvedic agencies also suggest patients who are suffering from cancer to take neutraceutical medicines made from algal origin.

In the present study, marine green alga Cladophora spp., has been used to treat with cancer cells in vitro. In the cytotoxicity test, the crude methanol extracts of Cladophora spp., was evaluated using methyl thiazoltetrazolium (MTT) assay. It involves the ability of the living cells to reduce the MTT compound which results in color changes.

\subsection{Collection of materials}

\section{Materials And Methods}

The collection of Cladophora spp., (Fig.1) was made during the low tide and subtidal regions (up to $1 \mathrm{~m}$ depth) by hand picking from Kanyakumari Coast (Latitude $8^{\circ} 14^{\prime} 23.10^{\prime \prime}$ N, Longitude $77^{\circ} 20^{\prime} 04.02^{\prime \prime} \mathrm{E}$ ), located in the South East Coast of Tamil Nadu, India. The collected materials were washed thoroughly with 
marine water in the field itself to remove the epiphytes and sediment particles. Then the samples were packed separately in polythene bags in wet conditions and brought to the laboratory, then thoroughly washed in tap water followed by distilled water to remove the salt on the surface of the thalli. For drying, washed specimens were placed on blotting paper and spread out at room temperature in the shade. The shade dried samples were grounded into fine powder using a tissue blender. The powdered samples were then stored in the refrigerator for further use.

\subsection{Reagents}

MEM was purchased from Hi Media Laboratories Fetal Bovine Serum (FBS) was purchased from Cistron laboratories Trypsin, methylthiazolyldiphenyl- tetrazolium bromide (MTT) and Dimethyl sulfoxide (DMSO) were purchased from Sisco research laboratory chemicals, Mumbai. All of other chemicals and reagents were obtained from Sigma Aldrich Mumbai.

\subsection{Extraction of seaweed sample}

The dried and powdered materials $(5 \mathrm{~g})$ were extracted successively with $250 \mathrm{~mL}$ of methanol by using a soxhlet extractor for $8 \mathrm{hrs}$ at a temperature not exceeding the boiling point of the solvent. The methanol extracts were filtered by using Whatman filter paper (No: 1) and then concentrated in vacuum at the $40^{\circ} \mathrm{C}$ using rotary evaporator. The residues obtained were stored in a freezer $-20^{\circ} \mathrm{C}$ until further tests.

\subsection{Cell line and cell culture}

HT-29 is a human colorectal adenocarcinoma cell line with epithelial morphology. These cells are sensitive to the chemotherapeutic drugs 5-fluorouracil and oxaliplatin, which are standard treatment options for colorectal cancer. In addition to being a xenograft tumor model for colorectal cancer, the HT-29 cell line is also used as an in vitro model to study absorption, transport and secretion by intestinal cells. Under standard culture conditions, these cells grow as a nonpolarized, undifferentiated multilayer. Altering culture conditions or treating the cells with various inducers, however, results in a differentiated and polarized morphology, characterized by the redistribution of membrane antigens and development of an apical brush-border membrane.

HT-29 human colorectal adenocarcinoma cell line was obtained from King Institute, Guindy, Chennai. The cancer cells were maintained in Minimal Essential Medium supplemented with $10 \%$ FBS, penicillin $(100 \mathrm{U} / \mathrm{mL})$ and streptomycin $(100 \mu \mathrm{g} / \mathrm{mL})$ in a humidified atmosphere of $50 \mu \mathrm{g} / \mathrm{mL} \mathrm{CO}_{2}$ at $37^{\circ} \mathrm{C}$. Cells were fed with fresh cultured medium every 2-3 times per week and subcultured when $80 \%$ confluent. All cultures were free of mycoplasma.

\subsection{Evaluation Cytotoxicity activity by MTT assay (Mosmann, 1983)}

Cells $\left(1 \times 10^{5} /\right.$ well $)$ were plated in 24 -well plates and incubated in $37^{\circ} \mathrm{C}$ with $5 \% \mathrm{CO}_{2}$ condition. After the cell reaches the confluence, the various concentrations of the samples were added and incubated for 24 hrs. After incubation, the sample was removed from the well and washed with phosphate-buffered saline (pH 7.4) or MEM without serum. $100 \mu \mathrm{L} /$ well $(5 \mathrm{mg} / \mathrm{mL})$ of $0.5 \%$ 3-(4, 5-dimethyl-2-thiazolyl)-2, 5-diphenyl-tetrazolium bromide (MTT) was added and incubated for $4 \mathrm{hrs}$. After incubation, $1 \mathrm{~mL}$ of DMSO was added in all the wells. The absorbance at $570 \mathrm{~nm}$ was measured with a UV-spectrophotometer using DMSO as the blank. Measurements were performed and the concentration required for a $50 \%$ inhibition $\left(\mathrm{IC}_{50}\right)$ was determined graphically. The $\%$ cell viability was calculated using the following formula:

$\%$ cell viability $=$ A570 of treated cells / A570 of control cells $\times 100$

\subsection{Statistical analysis}

The data on cell viability were analyzed by using the one way ANOVA followed by the Dennett's multiple comparison tests with equal sample size by using SPSS 17.0. The difference was considered significant when $\mathrm{p}<0.005$. All the values were expressed as mean \pm standard deviation (S.D). Triplicate assays were performed for each set of test conditions. 


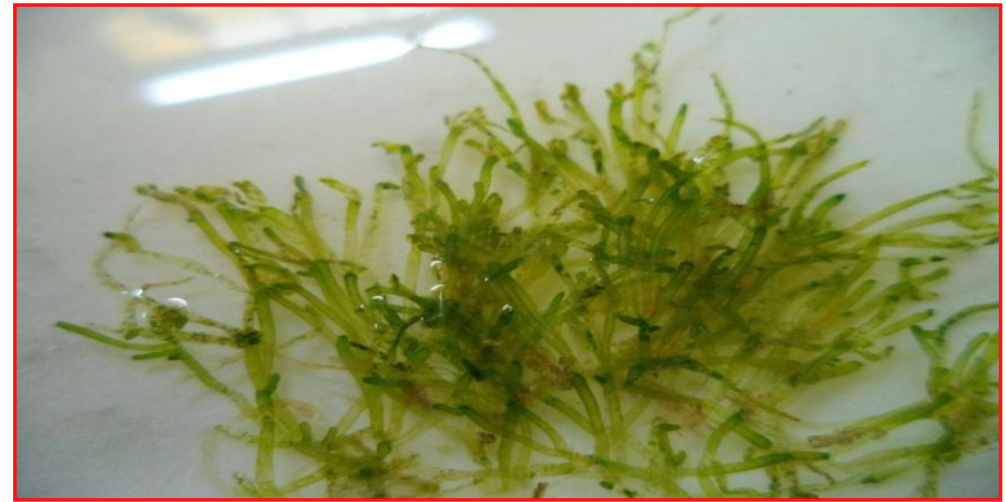

Fig.1 Photograph of the green alga Cladophora spp.,

\section{Results}

To assess the potential as anticancer drugs, the methanol extracts of green seaweed Cladophora spp., was investigated via the in vitro cytotoxicity against HT-29 human colon cancer cell line, using a MTT assay. While cytotoxic activity is determined as a decreased cell number because of cell death, cell-growth inhibition (CGI) or cytostatic activity is determined as a suppression of the increase of cell number without causing cell death. The variation in the activity among the methanol extract of Cladophora spp., was indicated by determining the $\mathrm{IC}_{50}$ of each extract against the particular cell line. The cytotoxic activity of methanol extracts of seaweed against human HT-29 cell line showed a dose and time-dependent inhibitory effect. IC $_{50}$ values methanol extracts of Cladophora spp., observed as $27.11 \mu \mathrm{g} / \mathrm{mL}$. The methanol extracts of Cladophora spp., showed potential inhibitory effect as compared to the cell control. MTT assay was carried out to investigate the inhibitory effects of methanol extracts of green marine alga Cladophora spp., on the growth of HT-29 cells and the results are represented in Figs. 2 \& 3. Eight different concentrations $(7.8,15.6,31.2,62.5,125,250,500$ and $1000 \mu \mathrm{g} / \mathrm{mL}$ ) of methanol extract were applied. Fig.3 shows the percentage of growth inhibition against the methanol extracts of Cladophora spp. The highest percentage (62.70\%) of growth inhibition was observed with the treatment using $7.8 \mu \mathrm{g} / \mathrm{mL}$ of methanol extract. This was followed by the treatment using methanol extracts at $15.6,31.2,62.5,125,250,500$ and $1000 \mu \mathrm{g} / \mathrm{mL}$ with $54.22,49.15,40.68,30.50,22.02,15.25$ and $10.16 \%$ of growth inhibition, respectively. Treatments with 500 and $1000 \mu \mathrm{g} / \mathrm{mL}$ methanol extracts did not show any growth inhibition. The methanol extract of Cladophora spp. significantly inhibited the proliferation of HT-29 cells in a dose dependent manner. The cell control showed $100 \%$ protection, the treatment with different concentration of methanol extracts from Cladophora spp., at $1000 \mu \mathrm{g} / \mathrm{mL}$ demonstrated growth inhibition $(10.16 \%)$ as summarized in Table.1. Increment of methanol extract concentrations resulted in the decrement of growth inhibition as seen with 250 and $500 \mu \mathrm{g} / \mathrm{mL}$ of extracts demonstrated 31.20 and $15.60 \%$ of growth inhibition, respectively. The results indicated that all the methanol extracts have positive inhibition on the HT-29 cell lines. The results of our study display that seaweeds methanol extracts have a cytotoxic effect against HT-29 human colon adenocarcinoma cells in a concentration dependent manner, the methanol extracts of Cladophora spp. showed a high therapeutic value against HT-29 human colon adenocarcinoma cells with $54.23 \mu \mathrm{g} / \mathrm{mL}$. Morphological studies also confirmed that the methanol extract of Cladophora spp. showed potent cytotoxic effect. It was observed that exposure to methanol seaweed extracts for $24 \mathrm{hrs}$, HT-29 cell growth was inhibited as it is clear from MTT assay and direct cell count (Fig.3). The morphological changes in cells clearly indicate that cells undergo apoptosis at $24 \mathrm{hrs}$ after incubation with the concentration of methanol extracts of seaweeds chosen based on the MTT assays (Fig.3). This indicates that methanol extracts of seaweed decrease the potential of individual cells to form a colony and thereby acts as an anticancer drug. This finding well corroborated by our cell proliferation and cell count studies.

Table.1 Effect of methanol extracts on human colon cancer cell line (HT-29 cell line)

\begin{tabular}{|c|c|c|c|c|}
\hline S.No & Concentration $(\boldsymbol{\mu g} / \mathbf{m L})$ & Dilutions & Absorbance (O.D) & Cell Viability (\%) \\
\hline 1 & 1000 & Neat & 0.06 & $10.16 \pm 0.00^{\mathrm{a}}$ \\
\hline 2 & 500 & $1: 1$ & 0.09 & $15.25 \pm 0.00^{\mathrm{b}}$ \\
\hline 3 & 250 & $1: 2$ & 0.13 & $22.02 \pm 0.01^{\mathrm{c}}$ \\
\hline 4 & 125 & $1: 4$ & 0.18 & $30.50 \pm 0.01^{\mathrm{d}}$ \\
\hline 5 & 62.5 & $1: 8$ & 0.24 & $40.68 \pm 0.01^{\mathrm{e}}$ \\
\hline 6 & 31.2 & $1: 16$ & 0.29 & $49.15 \pm 0.00^{\mathrm{f}}$ \\
\hline 7 & 15.6 & $1: 32$ & 0.32 & $54.22 \pm 0.01^{\mathrm{g}}$ \\
\hline 8 & 7.8 & $1: 64$ & 0.37 & $62.70 \pm 0.01^{\mathrm{h}}$ \\
\hline 9 & Cell control & - & 0.5910 .16 & 27.11 \\
\hline \multicolumn{3}{|c|}{ IC } & & 0.0000 \\
\hline \multicolumn{5}{|c|}{ P-Value } \\
\hline
\end{tabular}




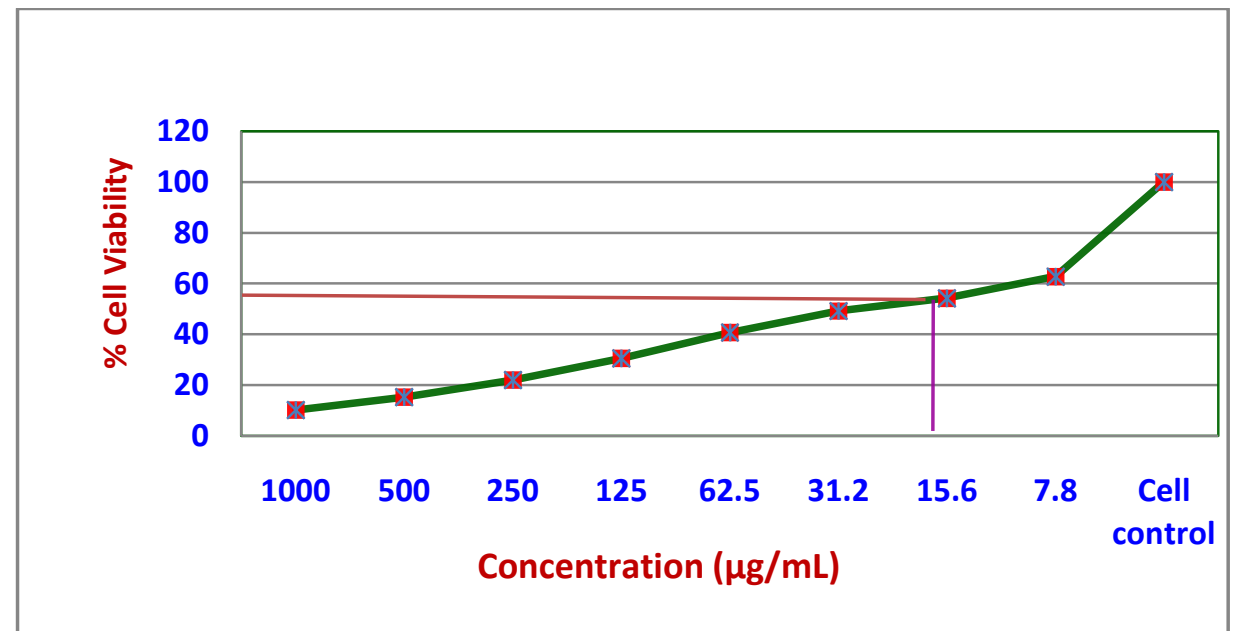

Fig.2. Percentage of growth inhibition of HT-29 cell lines in the presence of methanol extracts of Cladophora spp.

The results of the present study suggest that the methanol extract of Cladophora spp., may be used as anti-cancer drug in the near future. However, further study needs to elucidate the chemical nature and the active principle of Cladophora spp., which is responsible for its activity.

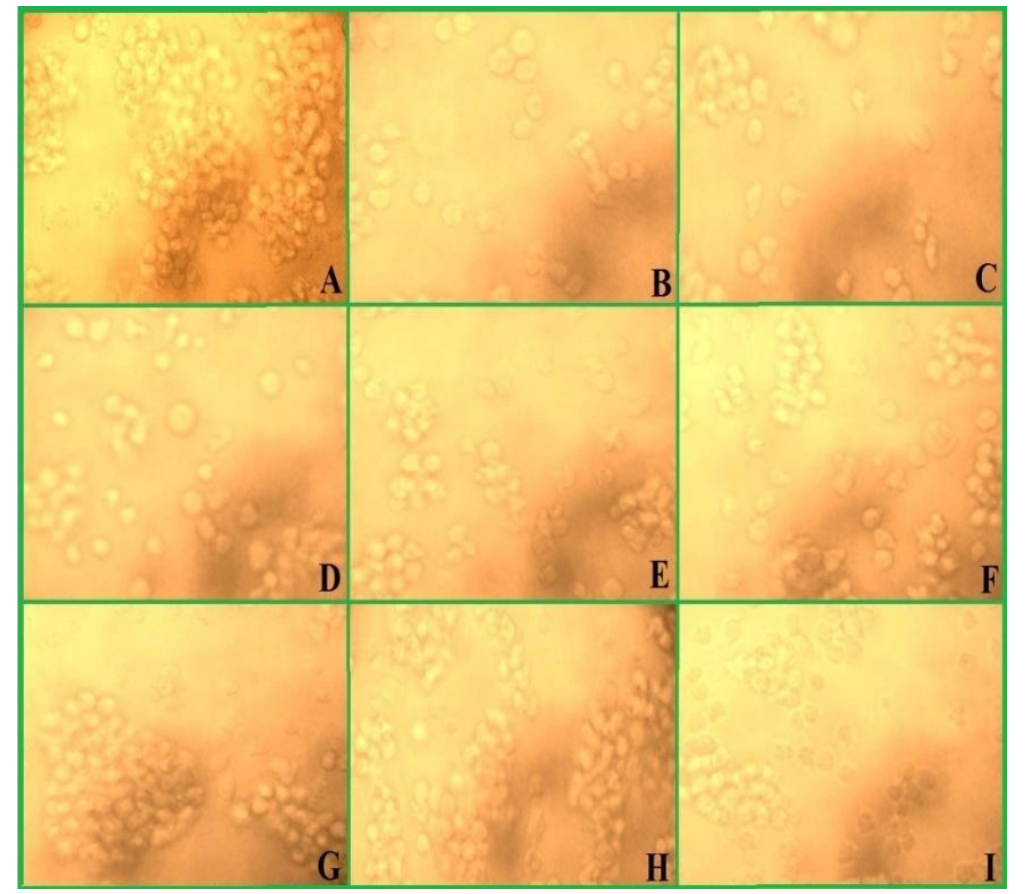

Fig.3 Inhibition of cell proliferation by methanol extracts of Cladophora spp.

\section{A - Normal HT-29 Cell line}

B - Methanol extract of HT-29 cell line treated with $1000 \mu \mathrm{g} / \mathrm{mL}$ of Cladophora spp..

C - Methanol extract of HT- 29 cell line treated with $500 \mu \mathrm{g} / \mathrm{mL}$ of Cladophora spp.

D - Methanol extract of HT-29 cell line treated with $250 \mu \mathrm{g} / \mathrm{mL}$ of Cladophora spp.

E - Methanol extract of HT-29 cell line treated with $125 \mathrm{mg} / \mathrm{mL}$ of Cladophora spp.

F - Methanol extract of HT-29 cell line treated with $62.5 \mu \mathrm{g} / \mathrm{mL}$ of Cladophora spp.

G - Methanol extract of HT-29 cell line treated with $31.2 \mu \mathrm{g} / \mathrm{mL}$ of Cladophora spp.

H - Methanol extract of HT-29 cell line treated with $15.6 \mu \mathrm{g} / \mathrm{mL}$ of Cladophora spp.

I - Methanol extract of HT-29 cell line treated with $7.8 \mu \mathrm{g} / \mathrm{mL}$ of Cladophora spp.

\section{Discussion}

Due to increasing the incidence of cancer in the world is increasing the production of chemotherapeutic drug from natural product like seaweeds or some other natural resource its give more attention in today's world. Because they never give any side effect and cost also very less that is why the search for anticancer agents from 
natural sources has been successful worldwide. Seaweed contains the anticancer compounds selenium, iodine and omega-3 fatty acids. In the current study, HT-29 cells at exponential phase were treated with methanol extracts of Cladophora spp. and the suitable duration of exposure to this cytotoxic agent was determined. Based on this study, the in vitro cytotoxicity of Cladophora spp.was determined using 3-(4, 5-dimethylthiasol-2-yl)-2, 4,-di phenyl tetrazoliumbromide (MTT) assay. It is a colorimetric test which commonly used to measure cell viability based on the ability of mitochondria in the viable cells to produce dehydrogenase enzyme (22). MTT is a water soluble tetrazolium salt, which turns yellowish when dissolves in solution.

In MTT assay, different concentrations of methanol extract of Cladophora spp. was used to treat with cancer cells. The absorbances at $570 \mathrm{~nm}$ with reference filter at $630 \mathrm{~nm}$ for $24 \mathrm{hrs}$ incubation. In this study, MTT cell viability test shown that various concentrations of the methanol extract from Cladophora spp. inhibited the growth of the HT-29 cancer cells for $24 \mathrm{hrs}$ incubated with methanol extracts from Cladophora spp. respectively. The cell viability percentage decreased gradually when the doses have been increased to 24 hrs. On the other hands, cell viability of fibroblast did not decrease even though the highest dose of $1000 \mathrm{mg} / \mathrm{mL}$ was applied. Consequently, the percentage of various cancer cell viability decreased in a dose dependent manner yet to prevent fibroblast, human normal cell lines from elimination. The most effective concentration to inhibit cell growth was found to be $15.6 \mu \mathrm{g} / \mathrm{mL}$ of methanol extract of Cladophora spp. with $54.23 \%$ of growth inhibition, respectively. As the concentration of the seaweed extract increases, the number of viable cells decreased. ${ }^{23}$ Joshi and Srisudha (2012) reported that extracts of Caulerpa scalpelliformis exhibited cytotoxic activity against Hep2 cells in vitro with a CD50 of $250 \mu \mathrm{g} / \mathrm{mL}$. Thus, the bioactive compounds of the current study with Cladophora $s p$ can be considered as a chemotherapeutic agent against cancer. $7.8 \mu \mathrm{g} / \mathrm{mL}$ of the seaweed extract exhibited $88.4 \%$ cell viability whereas $1000 \mu \mathrm{g} / \mathrm{mL}$ of the seaweed extract showed $11.5 \%$ cell viability. Increasing concentration of seaweed extract from 7.8 to $1000 \mu \mathrm{g} / \mathrm{mL}$ leads to $76.9 \%$ decrease in cell viability of HT-29 cell lines. These differences in antitumour activities may be attributed to their different molecular weights, charge characteristics and monosaccharide distributions (24)

${ }^{25} \mathrm{Xu}$ et al., (1992) reported that alcohol extracts from plant samples exhibited several bioactivities such as adaptogenic, anti-inflammatory, anticonvulsant, sedative, androgenic and immune promoting activities. This might be the reason why methanol extracts from Cladophora spp. showed positive growth inhibition to the HT-29 cell lines. Studies by ${ }^{26}$ Shao et al., (1996) also reported that an alcoholic extract from shoots exhibited antitumor activities and ${ }^{27}$ Singh et al., (1992) reported their fruit to be the source of bile-stimulating agent. Reports from World Intellectual Property Organization (2010) also indicated that methanol extracts from various seaweed species have demonstrated cytotoxic effect on human cancer cell lines including HeLa, MCF-7 and MDA-MB-231. Alcohol is found to be effective to extract active compounds such as biophenols, lipids, polysaccharides, minerals and small peptides due to their polarity. The potential bioactive compounds in seaweed may interact with special cancer associated receptors or cancer specific molecules to trigger the mechanisms leading to cancer cell death.

When metabolic events lead to apoptosis or necrosis, it showed a reduction in cell viability in MTT proliferation assay (28). The linear relationship between cell number and signal produced is established, thus allowing an accurate quantification of changes in the rate of cell proliferation. Therefore, outliers that were found among the absorbance readings were removed to ensure consistency of the results was established. Inaccurate cell seeding and inaccurate reagent pipetting might be the possible causes of the poor consistency of replicates.

The $\mathrm{IC}_{50}$ values of the extracts using the MTT assay against HT-29 cell lines revealed that the methanol extract of Cladophora spp., exerted a significant antiproliferative effect on the HT-29 cell lines. The methanol extracts of Cladophora spp. mediated antiproliferative activity is limited to the cancer cell line rather than the normal cell lines. This indicates that the specific inhibitory effect may be due to the apoptosis-inducing ability of the methanol extracts of Cladophora spp.in response to the defective gene expression in cancer cell lines rather than the normal cell line. The result of the present study suggests that the drug to be used as an antiproliferative against cancer cell lines rather than to possess cytotoxicity. With the significant antiproliferative activity of the methanol extracts of the Cladophora spp., against HT-29 human colon adenocarcinoma cells, the mechanisms of action could, possibly, be due to the dose dependent apoptosisinducing ability, by necrosis of cancer cell lines, by enhanced neoplastic transformation followed by apoptosis or by any other mechanisms related to epigenetic and signal transduction pathways. Phytochemicals such as vitamins (A, C, E, and $\mathrm{K})$, carotenoids, terpenoids, flavonoids, polyphenols, alkaloids, tannins, saponins, pigments, enzymes and minerals have been found to elicit anticancer activities. These metabolites obstruct various hormone actions and metabolic pathways associated with the development of cancer (29). The preliminary phytochemical analysis confirmed the alkaloids presence in the methanol extracts of selected seaweeds. The previous phytochemical and bio-efficacy studies on plants confirmed cytotoxic properties of alkaloids (30, $31 \& 32)$. The methanol extracts of selected seaweeds exhibited a significant antiproliferative activity against HT-29 human colon adenocarcinoma cells. Hence, the presence of alkaloids in the methanol 
extracts of selected seaweed could be induced to the observed significant antiproliferative activity against human cancer cell lines.

According to the ${ }^{33}$ Suffness and Pezzuto (2009), a crude extract can be considered as cytotoxic against carcinoma cells in vitro and can be used for anticancer drug development if the standard $\mathrm{IC}_{50}$ value is less than $30 \mu \mathrm{g} / \mathrm{mL}$. Based on the results, Cladophora spp. are considered as highly cytotoxic against HT29 cell lines. This lack of cytotoxic activity might be due to masking of biological activity by the presence of some inhibitory compounds in the crude extract (34). Based on the standard values of toxicity by ${ }^{33}$ Suffness and Pezzuto (2009), Cladophora spp. are not possible sources of cytotoxic compounds.

In fact, only a few investigations on the antitumor potential of Cladophora species have been reported. ${ }^{35} \mathrm{Feng}$ et al., (2007) reported the potential of a novel vanillic acid derivative $\left(\mathrm{IC}_{50}=3.7 \mu \mathrm{M}\right)$ and its sulfate adduct $\left(\mathrm{IC}_{50}=1.7 \mu \mathrm{M}\right)$ isolated from $C$. socialis to prevent cancer by inhibiting considerably the activity of protein tyrosine phosphatase 1B (PTP1B). Drugs targeting phosphatases are considered as promising novel cancer therapies. Recently, ${ }^{36} \mathrm{Tang}$ et al., (2012) isolated some cyclic tetrapyrrolic photosensitizers from C. patentiramea and demonstrated that they exhibit important photo toxicity against HL60 promyelocytic leukemia cells. To date, a number of photosensitizers derived from natural products have been clinically approved for the photo dynamic therapy of specific cancers (37). Furthermore, ${ }^{38}$ Laungsuwon and Chulalaksananukul (1995) found that the ethyl acetate extract of C.glomerata possesses growth inhibitory activity (IC50=1420 $\mu \mathrm{g} / \mathrm{g}$ ) against the KB cell lines (epidermoid carcinoma of the oral cavity) in vitro. More recently ${ }^{39} \mathrm{Cha}$ et al., (2014) reported askin cancer protective effect of 3, 4-dihydroxybenzoic acid isolated from C.wrightiana Harvey by protecting human keratinocytes against UVB-induced apoptosis and oxidative stress. Thus, future researches are needed to elucidate the antiproliferative mechanism of $C$. prolifera; also the identification of the bioactive compounds of this seaweed will lead to their evaluation for uses in medicine, food production and cosmetic industry.

Further studies are suggested to identify the specific anti-tumoral compounds in the targeted extracts. Purification can be carried out to obtain the bioactive compounds for the development of cancer therapy. Besides, identification of specific metabolites from seaweeds is also recommended for the discovery of potential anti-proliferative or anticancer compounds. Owing to a diverse chemical ecology, the marine organisms, especially marine flora have a great promise for providing potent, cheaper, and safer anticancer drugs, which deserve an extensive investigation.

\section{Conclusion}

The present study has demonstrated that green seaweed Cladophora spp., has good anticancer and strong cytotoxicity characteristic of HT-29 cell line in vitro. Although the specific bioactive compounds which responsible for the anticancer properties of Cladophora spp. have yet to be explored. It can be a new source as new marine resource for antitumor medicine and to demonstrate that marine algae can be a potential candidate sources as antitumor drugs. In future studies, different assay can be carried out or the same methods can be done on other cancer cell line followed by an in vivo test in order to prove the anticancer effect of Cladophora spp.on animal models.

\section{References}

[1] Chandini SK, Ganesan P, Suresh P, Bhaskar N. Antioxidant properties of methanol extract and its solvent fractions obtained from selected Indian red seaweeds. Journal of Food Science and Technology.2008; 45:1-13.

[2] Holdt SL,Kraan S,. 'Bioactive compounds in seaweed; functional food applications and legislation'. Journal of Applied Phycology.2011; 23: 543-597.

[3] Bhadury P, Mohammad BT, Wright, PC. Journal of Industrial Microbiology and Biotechnology. 2006; 33: $325-337$.

[4] Ly BM., Buu NQ, Nhut ND, Thinh, PD, Thi, T, Van T. .Studies on fucoidan and its production from Vietnamese brown seaweeds.Asean Journal for Science and Technology Development (AJSTD).2005; 22: 371-380.

[5] Matsuda Y, Teruya K, Matsuda S, Nakano A, Nishimoto T, Ueno M, Niho A, Yamashita M, Eto H, Katakura Y,Shirahata S. Anticancer effects of enzyme-digested fucoidan extract from seaweed Mozuku. Animal Cell Technology: Basic \& Applied Aspects.2010; 16: 295-300.

[6] Itoh H, Noda H, Amano H, Zhuang C, Mizuno T, Ito, H. Antitumor activity and immunological properties of marine algal polysaccharides, especially fucoidan, prepared from Sargassum thunbergii of phaeophyceae. Anticancer Research. 1993;13: 20452052.

[7] Maruyama H, Tamauchi, H, Hashimoto M, Nakano T. Antitumor activity and immune response of Mekabufucoidan extracted from Sporophyll of Undariapinnatifida. In vivo. 2003; 17: 245-249.

[8] Noda H, Amano H, Arashima K,Nisizawa K. Antitumor activity of marine algae. Hydrobiologia. 1990;204-205: 577-584

[9] Usui T, Asari K,Mizuno T.Isolation of highly purified "Fucoidan" from Eiseniabicylclis and its anticoagulant and antitumor activities.Agricultural and Biological Chemistry. 1980; 44: 1965-1966.

[10] Yamamoto I, Takahashi M, Suzuki T, Seino, H, Mori, H. Antitumor effect of seaweeds. IV. Enhancement of antitumor activity by sulfation of a crude fucoidan fraction from Sargassum kjellmanianum. The Japanese Journal of Experimental Medicine.1984; 54: 143-151.

[11] Zhuang C, Itoh, H, Mizuno, T,Ito H.Antitumor active fucoidan from the brown seaweed, umitoranoo (Sargassumthunbergii).Bioscience, Biotechnology, and Biochemistry 1995;59: 563-567. 
[12] Singh SK, Hawkins C, Clarke ID, Squire JA, Bayani J, Hide T, Henkelman RM, Cusimano MD, Dirks PB. Identification of human brain tumour initiating cells. Nature. 2004;18;432(7015):396-401.

[13] Bao S, Wu Q, Sathornsumetee S, Hao Y, Li Z, Hjelmeland AB, Shi Q, McLendon RE, Bigner DD, Rich JN. Stem cell-like glioma cells promote tumor angiogenesis through vascular endothelial growth factor. Cancer research. 2006; 66(16): 7843-7848.

[14] Garcia M, Jemal A, Ward E, Center M, Hao Y, Siegel R, Thun M. Global cancer facts \& figures. Atlanta, GA: American Cancer Society. 2007; 1(3).

[15] Ferlay J, Soerjomataram I, Ervik M, Dikshit R, Eser S, Mathers C, Rebelo M, Parkin DM, Forman D, Bray F. International Agency for Research on Cancer; Lyon, France: 2013; Cancer incidence and mortality worldwide: GLOBOCAN 2012 v1.0, IARC Cancer Base No. 11

[16] Kim EJ, Park SY, Lee JY, Park JH. Fucoidan present in brown algae induces apoptosis of human colon cancer cells. BMC astroenterol. 2010; 10:96. doi: 10.1186/1471-230X-10-96.

[17] Siegel R., Naishadham D., Jemal A. Cancer statistics. CA Cancer J.Clin. 2012;62:10-29.

[18] Yuan YV, Walsh NA.Antioxidant and antiproliferative activities of extracts from a variety of edible seaweeds. Food and Chemical Toxicology.2006; 44(7): 1144-1150.

[19] Berge J, Debiton E, Dumay J, Durand P, Barthomeuf C. In vitro anti-inflammatory and anti-proliferative activity of sulfolipids from the red alga Porphyridium cruentum. Journal of agricultural and food chemistry.2002; 50(21): 6227-6232.

[20] Harada H, Noro T, Kamei Y. Selective antitumor activity in vitro from marine algae from Japan coast. Biol. Pharm. Bull. 1997; 20: 541-546.

[21] Song L, Ren S, Yu R, Yan C, Li T, Zhao Y. Purification, Characterization and in vitro Anti-tumor Activity of Proteins from Arcaasubcrenata Lischke. Marine Drugs. 2008;6: 418-430.

[22] Yedjou CG and Tchounwou PB. In-vitro cytotoxic and genotoxic effects of arsenic trioxide on human leukemia (HL-60) cells using the MTT and alkaline single cell gel electrophoresis (Comet) assays. Molecular and Cellular Biochemistry.2007; 301: 123-130.

[23] Joshi NVM, Srisudha S, Haemagglutinin. Activity of a few selected seaweeds from Mandapam coast, TamilNadu. International Journal of Current Research; 4:49-55. Journal of oncology.2012; 2011; 2010.

[24] Dias PF, Siqueira JM, Vendruscolo LF, de Jesus Neiva, T, Gagliardi, AR, Maraschin, M,Ribeiro-do-Valle RM.Antiangiogenic and antitumoral properties of a polysaccharide isolated from the seaweed Sargassumstenophyllum. Cancer Chemotherapy and Pharmacology. 2005; 56: 436-446.

[25] Xu, JP, Xu, RS,Li XY.Four new cycloartanesaponins from Curculigoorchioides. PlantaMedica. 58.1992; $208-210$.

[26] Shao Y, Chin CK, Ho, CT, Ma, W, Garrospm, SA. Huang, M.T. Anti-tumor activity of the crude saponins obtained from asparagus. Cancer Letters. 1996;104: 31-36.

[27] Singh AK., Hussain A, Srivastava, GN, Misra, LN, Gupta, MM, Virmani, OP, Popli, SP,Abraham, Z. 1992.Dictionary of Indian Medicinal Plants. Lucknow, India: Central Institute of Medicinal and Aromatic Plants (CIMAP).

[28] Selvi S, Umadevi P, Murugan S, GiftsonSenapathy J. Anticancer potential evoked by Pleurotusfloridaand Calocybeindicausing T24 urinary bladder cancer cell line. African Journal of Biotechnology.2011;10(37): 7279-7285.

[29] Gacche RN, Shaikh RU, Pund MM. In vitro evaluation of anticancer and ntimicrobial activity of selected medicinal plants from Ayurveda. Asian Journal of Traditional Medicines. 2011; 6 (3).127-133.

[30] Griffin C, Sharda N, Sood D, Nair J, McNulty J, Pandey S. Selective cytotoxicity of Pancratistatinrelated natural Amaryllidaceae alkaloids: Evaluation of the activity of two new compounds. CancerCellInt, 2007; 7.10.

[31] Suresh HM, Shivakumar B, Hemalatha K, Heroor SS, Hugar DS and Sambasiva Rao KRS. In vitro antiproliferativeactivity of Annonareticulataroots on human cancer cell lines. Pharmacognosy Res. 2011; 3(1). 9-12

[32] Chougule M, Patel AR, Sachdeva P, Jackson T, Singh M.Anticancer activity of Noscapine an Opoid alkaloid in combination with Cisplatin in human non-small cell lung cancer. Lung Cancer. 2010; 6.2.

[33] Suffness M, Pezzuto JM. Assay related to cancer drug discovery. In: Hostettman K, editor. Methods in plant biochemistry: assay for bioactivity. London: Academic Press.2009; 71-133.

[34] Nasrin M, Dash PR, Ali MS. In vitro antibacterial and in Vivo cytotoxic activities of Grewiapaniculata. Avicenna J Phytomed. 2015; 5(2), 98-104.

[35] Feng Y, Carroll AR, Addepalli R, Fechner GA, Avery VM, Quinn RJ. Vanillic acid derivatives from the green algae Cladophorasocialisas potent protein tyrosine phosphatase 1B inhibitors. J Nat Pro.2007.; 70(11): 1790-92.

[36] Tang YV, Phang SM, Chu WL, Ho A, Teo SH, Lee HB.Cyclic tetrapyrrolic photosensitizers from Cladophorapa tentiramea (Cladophoraceae, Chlorophyta) and Turbinaria conoides(Sargassaceae, Phaeophyta) for photodynamic therapy. JApplPhycol.2012; 24(4): 783-90.

[37] Majumdar P, Nomula R, Zhao J. Activatable triplet photosensitizers: Magic bullets for targeted photodynamic therapy. J Mater Chem. C. 2014; 2(30): 5982-97.

[38] Laungsuwon R, Chulalaksananukul W. Antioxidant and anticancer activities of freshwater green algae, Cladophoraglomerataand Microsporafloccosa, from Nan River in northern Thailand.Maejo Int. J. Sci. Technolx; 1995;7(02): 181-88.

[39] Cha JW, Piao MJ, Kim KC, Zheng J, Yao CW, Hyun CL, Kang HK, Yoo ES, Koh YS, Lee NH, Ko MH, Hyun JW. 2014. Protective effect of 3, 4-dihydroxybenzoic acid isolated from Cladophora wrightiana Harvey against ultraviolet B radiation-induced cell damage in human HaCaT keratinocytes. Appl Biochem Biotechnol; 172(5): 2582-92. 